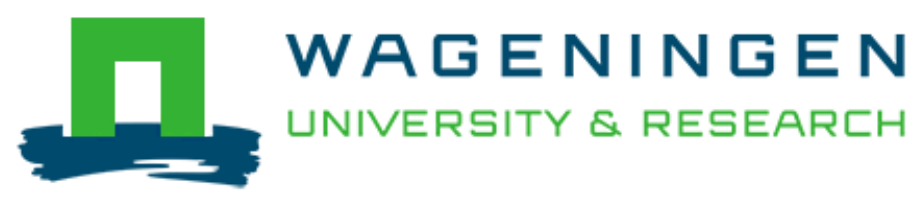

Multigram Scale Enzymatic Synthesis of (R)-1-(4'-Hydroxyphenyl)ethanol Using Vanillyl Alcohol Oxidase

Ewing, T. A., Kühn, J., Segarra, S., Tortajada, M., Zuhse, R., \& van Berkel, W. J. H.

This article is made publically available in the institutional repository of Wageningen University and Research, under article 25fa of the Dutch Copyright Act, also known as the Amendment Taverne.

Article $25 \mathrm{fa}$ states that the author of a short scientific work funded either wholly or partially by Dutch public funds is entitled to make that work publicly available for no consideration following a reasonable period of time after the work was first published, provided that clear reference is made to the source of the first publication of the work.

For questions regarding the public availability of this article, please contact openscience.library@wur.nl.

Please cite this publication as follows:

Ewing, T. A., Kühn, J., Segarra, S., Tortajada, M., Zuhse, R., \& van Berkel, W. J. H. (2018). Multigram Scale Enzymatic Synthesis of (R)-1-(4'-Hydroxyphenyl)ethanol Using Vanillyl Alcohol Oxidase. Advanced Synthesis and Catalysis, 360(12), 23702376. https://doi.org/10.1002/adsc.201800197 


\title{
Multigram Scale Enzymatic Synthesis of (R)-1-(4'-Hydroxyphenyl) ethanol Using Vanillyl Alcohol Oxidase
}

\author{
Tom A. Ewing, ${ }^{a}$ Jasmin Kühn, ${ }^{b}$ Silvia Segarra, ${ }^{c}$ Marta Tortajada, ${ }^{c}$ Ralf Zuhse, \\ and Willem J. H. van Berkel ${ }^{a, *}$ \\ a Laboratory of Biochemistry, Wageningen University \& Research, Stippeneng 4, 6708 WE Wageningen, The Netherlands \\ Phone: + 31317482861, Fax: + 31317484801 \\ E-mail: willem.vanberkel@wur.nl \\ b Chiracon GmbH, Biotechnologiepark, 14943 Luckenwalde, Germany \\ c Biopolis S. L., Parc Científic de la Universitat de València, Edificio 2, C/Catedrático Agustín Escardino 9, 46980 Paterna, \\ Spain
}

Received: February 7, 2018; Revised: March 29, 2018; Published online: April 20, 2018

Supporting information for this article is available on the WWW under https://doi.org/10.1002/adsc.201800197

\begin{abstract}
The enantioselective oxyfunctionalisation of $\mathrm{C}-\mathrm{H}$ bonds is a highly interesting reaction, as it provides access to chiral alcohols that are important pharmaceutical building blocks. However, it is hard to achieve using traditional methods. One way in which it can be achieved is through the action of oxidative enzymes. Although many reports of the oxyfunctionalisation capabilities of enzymes at an analytical scale have been published, reports on the use of enzymes to achieve oxyfunctionalisation on a synthetically relevant scale are fewer. Here, we describe the scale-up of the conversion of 4-ethylphenol to $(R)-1-\left(4^{\prime}\right.$-hydroxyphenyl)ethanol using the flavin-dependent enzyme vanillyl alcohol oxidase. The process was optimised by testing different reaction media and substrate and enzyme concentrations and by performing it under an oxygen atmosphere. Under optimised reaction conditions, $4.10 \mathrm{~g}(R)$-1-(4'-hydroxyphenyl)ethanol at $97 \%$ ee was obtained from $10 \mathrm{~g}$ 4-ethylphenol (isolated yield $36 \%$ ). These results highlight some of the challenges that can be encountered during scale-up of an enzymatic oxyfunctionalisation process to a synthetically relevant scale and will be of use for the development of enzymatic processes for the synthesis of industrially relevant compounds.
\end{abstract}

Keywords: Alcohols; Alkylphenols; Enantioselectivity; Flavoprotein; Hydroxylation; Oxidoreductases

The selective oxyfunctionalisation of $\mathrm{C}-\mathrm{H}$ bonds under mild reaction conditions is of great interest to synthetic organic chemists. In recent years, much effort has been put into developing metal-based catalysts that can introduce oxygen atoms using environmentally benign oxidants such as molecular oxygen. ${ }^{[1,2]}$ An attractive alternative to traditional chemical catalysts is the use of enzymes capable of introducing oxygen atoms, which often display exquisite regio- and enantioselectivity and are active under mild reaction conditions. Well-known classes of oxygenating enzymes include heme-dependent cytochrome P450 enzymes and peroxygenases, non-heme iron oxygenases and flavin-dependent oxygenases. ${ }^{[3-7]}$ Some of these enzymes have been utilised to obtain valuable products from preparative-scale transformations. ${ }^{[8-12]}$ For many others, however, our knowledge of their oxyfunctionalisation capabilities is limited to the analytical scale. In order to stimulate the use of oxidoreductases in industrial chemical synthesis, it is crucial to demonstrate that they can be used to obtain compounds on a synthetically relevant scale. ${ }^{[13]}$

Chiral alcohols, which are often important intermediates in the synthesis of active pharmaceutical ingredients, present an interesting target for these preparative-scale transformations. ${ }^{[14]}$ One class of alcohols that are important pharmaceutical building blocks are chiral $\alpha$-aryl alcohols. ${ }^{[15,16]}$ A number of biocatalytic approaches for their synthesis have been described, including enantioselective reduction of a prochiral ketone, kinetic resolution or deracemisation of racemic alcohols and the enantioselective hydration of vinylphenol derivatives. ${ }^{[17-22]}$ Another potential enzymatic synthesis route for chiral $\alpha$-aryl alcohols is the direct oxyfunctionalisation of alkyl-substituted aromatic molecules. An enzyme that can be used for this purpose is vanillyl alcohol oxidase from Penicillium simplicissimum (VAO, EC 1.1.3.38), which is capable of catalysing the enantioselective hydroxyla- 
tion of 4-alkylphenols. Here, we describe the development of the multigram scale enzymatic synthesis of (R)-1-(4'-hydroxyphenyl)ethanol using VAO. This compound may be of use for the synthesis of bioactive molecules containing 1-(4'-hydroxyphenyl)ethanol moieties. For example, racemic 1-(4'-hydroxyphenyl) ethanol has been employed as an intermediate in the synthesis of artemisinin derivatives that display immunosuppressive activity, though the bioactive enantiomer was not defined. ${ }^{[23]}$

VAO catalyses the oxidation of a wide range of para-substituted phenols at their $\mathrm{C} \alpha$ atom using molecular oxygen as an electron acceptor. ${ }^{[2,25]} \mathrm{VAO}$ displays a broad substrate scope, catalysing the oxidation of benzylic alcohols or amines, the oxidative demethylation of 4-(methoxymethyl)phenol and the hydroxylation of 4-allylphenols. In addition, VAO oxidises phenols bearing unfunctionalised alkyl chains as the para-substituent. This leads to mixtures of hydroxylated and dehydrogenated products, with the ratio between the two being determined by the size of the alkyl chain ${ }^{[26,27]}$ and the composition of the reaction medium. ${ }^{[28]}$ The hydroxylation of short chain 4-alkylphenols proceeds with high regio- and enantioselectivity. The conversion of 4-ethylphenol, 4-propylphenol or 2-methoxy-4-propylphenol by VAO yields the corresponding 1-(4'-hydroxyphenyl)alcohols as the sole hydroxylation product, in addition to more minor amounts of vinylic side-products from dehydrogenation of the substrate and ketone side-products from further oxidation of the formed alcohols (Scheme 1). ${ }^{[29]}$ The hydroxylation reaction is highly enantioselective, with the $(R)$-enantiomers of the alcohol product being formed at $94 \%$ ee in all cases.

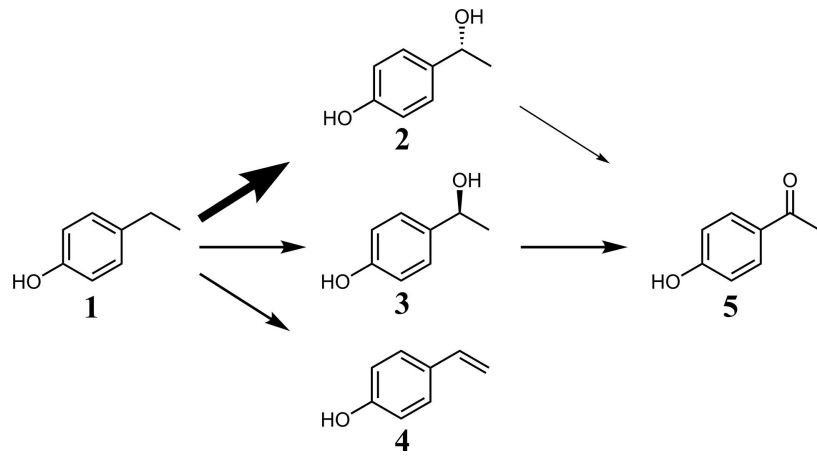

Scheme 1. Conversion of 4-ethylphenol (1) by VAO. Thickness of the arrows gives a qualitative indication of the relative rates at which the depicted reactions occur. VAO readily converts 4-ethylphenol to $(R)-1$-(4'-hydroxyphenyl) ethanol (2), with $(S)$-1-(4'-hydroxyphenyl)ethanol (3) and 4vinylphenol (4) being formed as side-products. The formed alcohol can subsequently be oxidised further to 4-hydroxyacetophenone (5), with the $(S)$-enantiomer being more readily converted than the $(R)$-enantiomer. Scheme adapted from. ${ }^{[26]}$
The catalytic mechanism of VAO provides an explanation for this regio- and enantioselectivity. ${ }^{[30-32]}$ Binding of the phenolate form of the substrate to the active site is followed by hydride transfer from the $\mathrm{C} \alpha$ atom of the substrate to the $\mathrm{N} 5$ atom of the FAD cofactor (Scheme 2). This yields a planar para-quinone methide intermediate, which is subsequently hydrated in the enzyme's active site. The enantioselectivity of the hydration is determined by the presence of an active site base (Asp-170) that activates water for attack at one side of the planar para-quinone methide intermediate. Accumulation of the $(R)$-enantiomer is further enhanced by the fact that the $(S)$-enantiomer of 1-(4'-hydroxyphenyl)ethanol is more easily oxidised further to 4-hydroxyacetophenone than the $(R)$-enantiomer is. ${ }^{[26]}$ A VAO variant (D170S/T457E) where the active site base was moved to the other side of the substrate displayed reversed enantioselectivity, converting 4-ethylphenol to $(S)$-1-(4'-hydroxyphenyl) ethanol at $80 \% e e^{[33]}$ Its ability to catalyse regio- and enantioselective hydroxylations using only molecular oxygen as a cosubstrate makes VAO an interesting candidate for biocatalytic applications.

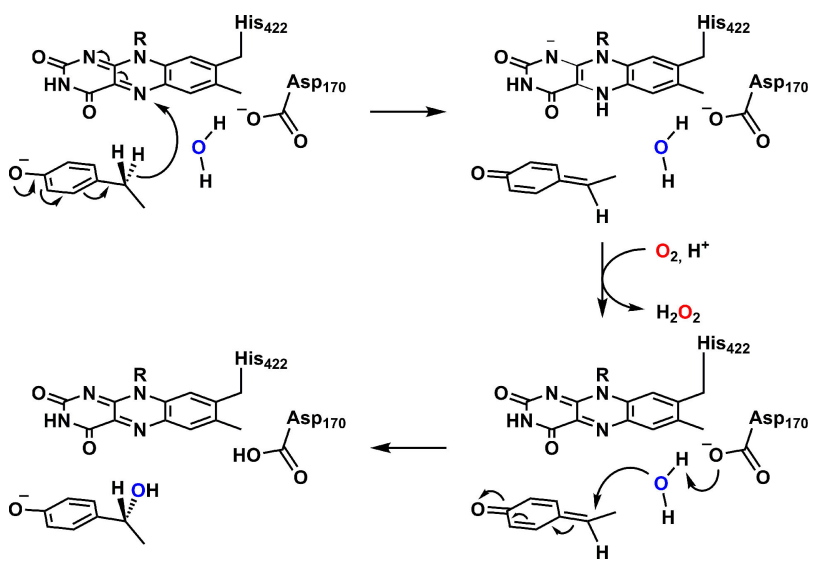

Scheme 2. Mechanism of the enantioselective hydroxylation of 4-ethylphenol by VAO. First, 4-ethylphenol binds in the enzyme's active site in its phenolate form. Following this, a hydride is transferred from the $\mathrm{C} \alpha$ atom of its ethyl group to the N5 atom of FAD, yielding a para-quinone methide intermediate and reduced FAD. Subsequently, a water molecule is activated by Asp-170 and attacks the $\mathrm{C} \alpha$ atom of the para-quinone methide intermediate, yielding the alcohol product. Stopped-flow kinetics analysis has demonstrated that this occurs after (or possibly concomitant to) the reoxidation of FAD by molecular oxygen. ${ }^{[31]}$ The position of Asp-170 relative to the planar para-quinone methide intermediate explains the preferential formation of the $(R)$ enantiomer of 1-(4'-hydroxyphenyl)ethanol.

The synthetic utility of VAO at small scale has been demonstrated previously. The conversion of 4ethylphenol and 2-methoxy-4-propylphenol was per- 
formed at $100 \mathrm{mg}$ scale, yielding $33.2 \mathrm{mg}$ (28\%) and $52 \mathrm{mg}(45 \%)$ respectively of the corresponding purified alcohols. ${ }^{[2]}$ To evaluate the potential of VAO to be used as a biocatalyst for the synthesis of chiral alcohols on a more synthetically relevant scale, we scaled up the conversion of 4-ethylphenol to the $10 \mathrm{~g}$ scale.

As a first step in the scale-up process, we optimised the reaction conditions for the conversion of 4-ethylphenol (1) at an analytical scale by testing the effect of the addition of organic solvents to the reaction medium. To this end, the conversion of $5 \mathrm{mg} 1$ was performed in $84 \mathrm{mM}$ potassium phosphate buffer, $\mathrm{pH} 7.5$, in the presence of $10 \%$ acetone or acetonitrile. The composition of reaction mixtures after the reaction as determined by gas chromatography is given in Table 1. Using acetone as a cosolvent gave the best

Table 1. Products obtained from the conversion of 4-ethylphenol (1) by VAO in the presence of organic solvents. $5 \mathrm{mg}$ 1 (at a concentration of $2.9 \mathrm{mM}$ ) and $0.4 \mathrm{U}$ VAO were incubated in $84 \mathrm{mM}$ potassium phosphate buffer, $\mathrm{pH} 7.5$, at $30{ }^{\circ} \mathrm{C}$ in the presence of $10 \%$ acetone or $10 \%$ acetonitrile. After the incubation period, reaction products were extracted and analysed by GC. Compounds are numbered as in Scheme 1. GC chromatograms are shown in Figure S1. The given numbers are the amount of a compound as a percentage of the total present upon analysis.

\begin{tabular}{lllllll}
\hline $\begin{array}{l}\text { Reaction } \\
\text { conditions }\end{array}$ & $\begin{array}{l}\mathbf{1} \\
(\%)\end{array}$ & $\begin{array}{l}\mathbf{2} \\
(\%)\end{array}$ & $\begin{array}{l}\mathbf{3} \\
(\%)\end{array}$ & $\begin{array}{l}\mathbf{2}-e e \\
(\%)\end{array}$ & $\begin{array}{l}\mathbf{4} \\
(\%)\end{array}$ & $\begin{array}{l}\mathbf{5} \\
(\%)\end{array}$ \\
\hline 10\% acetone, $4 \mathrm{~h}$ & - & 83 & 0.7 & 98 & 14 & 3.0 \\
$10 \%$ acetonitrile, $22 \mathrm{~h}$ & 5.9 & 76 & 2.5 & 94 & 14 & 1.3 \\
\hline
\end{tabular}

results, with complete conversion of $\mathbf{1}$ and $83 \%$ of the formed product being $(R)-1-\left(4^{\prime}\right.$-hydroxyphenyl) ethanol (2) after $4 \mathrm{~h}$. The formation of $\mathbf{2}$ is underestimated, as part of the 1-(4'-hydroxyphenyl)ethanol undergoes elimination of water during the gas chromatographic analysis, yielding 4-vinylphenol (4) [as confirmed by GC analysis of racemic pure 1-(4'hydroxyphenyl)ethanol]. The addition of acetone likely improves the solubility of the aromatic substrate and products. In addition, the solubility of oxygen in acetone is increased as compared to in water [277 mg/ $\mathrm{L}$ in acetone at $25^{\circ} \mathrm{C}$ and $44 \mathrm{mg} / \mathrm{L}$ in water at $20^{\circ} \mathrm{C}$ at 1 bar pure oxygen atmosphere ${ }^{[34]}$, preventing oxygen depletion from becoming limiting for the reaction. Although the solubility of the substrates may be increased further by using even higher concentrations of acetone, its presence led to significant inhibition of the enzyme. The rate of conversion of $2 \mathrm{mM}$ vanillyl alcohol to vanillin by $\mathrm{VAO}$ in $50 \mathrm{mM}$ potassium phosphate buffer, $\mathrm{pH} 7.5$, at $25^{\circ} \mathrm{C}$ dropped from $2.2 \mathrm{~s}^{-1}$ in the absence of acetone to $0.73 \mathrm{~s}^{-1}$ in the presence of $10 \%$ acetone and $0.12 \mathrm{~s}^{-1}$ in the presence of $20 \%$ acetone. With this in mind, scale-up was performed using the reaction medium containing $10 \%$ acetone.

Scaling up the reaction to $100 \mathrm{mg}$ scale with increased substrate concentrations revealed that almost complete conversion (97\%) could be achieved using a substrate concentration of $23 \mathrm{mM}$ and $2 \mathrm{U}$ VAO (Table 2, reaction a). Increasing the substrate concentration further to $45 \mathrm{mM}$ led to lower conversion $(87 \%)$ even though the same enzyme to substrate ratio was used (Table 2 , reaction $b$ ). Therefore, $23 \mathrm{mM}$

Table 2. Products obtained from the conversion of 4-ethylphenol (1) by VAO. $\mathbf{1}$ and VAO or His-VAO cell-free extract were incubated in $88 \mathrm{mM}$ potassium phosphate buffer, $\mathrm{pH} 7.5$, containing $10 \%$ acetone at $30^{\circ} \mathrm{C}$ for $24 \mathrm{~h}$. Subsequently, reaction products were extracted and analysed by GC or ${ }^{1} \mathrm{H}-\mathrm{NMR}$. Compounds are numbered as in Scheme 1 . GC chromatograms are shown in Figure S2, ${ }^{1} \mathrm{H}$-NMR spectra in Figure S4. The given numbers are the amount of a compound as a percentage of the total present upon analysis. CFE: cell-free extract.

\begin{tabular}{|c|c|c|c|c|c|c|c|c|c|c|}
\hline Reaction & & Substrate & Enzyme & $\begin{array}{l}1 \\
(\%)\end{array}$ & $\begin{array}{l}2 \\
(\%)\end{array}$ & $\begin{array}{l}3 \\
(\%)\end{array}$ & $\begin{array}{l}\mathbf{2}+\mathbf{3} \\
(\%)\end{array}$ & $\begin{array}{l}\text { 2-ee } \\
(\%)\end{array}$ & $\begin{array}{l}4 \\
(\%)\end{array}$ & $\begin{array}{l}5 \\
(\%)\end{array}$ \\
\hline $\mathrm{a}$ & GC & $\begin{array}{l}100 \mathrm{mg} \\
23 \mathrm{mM}\end{array}$ & $2 \mathrm{U} \mathrm{VAO}$ & 3.1 & 83 & 4.0 & & 91 & 8.3 & 1.5 \\
\hline $\mathrm{b}$ & GC & $\begin{array}{l}100 \mathrm{mg} \\
45 \mathrm{mM}\end{array}$ & $2 \mathrm{U} \mathrm{VAO}$ & 13 & 58 & 4.1 & & 87 & 24 & 1.0 \\
\hline c & GC & $\begin{array}{l}100 \mathrm{mg} \\
23 \mathrm{mM}\end{array}$ & 2 U His-VAO CFE & 0.8 & 74 & 2.1 & & 95 & 23 & 0.9 \\
\hline d & GC & $\begin{array}{l}1.0 \mathrm{~g} \\
23 \mathrm{mM}\end{array}$ & $20 \mathrm{U}$ His-VAO CFE & 6.5 & 83 & 1.3 & & 97 & 8.6 & 0.8 \\
\hline & ${ }^{1} \mathrm{H}-\mathrm{NMR}$ & & & 7.5 & & & 88 & & 2.6 & 1.8 \\
\hline $\mathrm{e}$ & $\mathrm{GC}$ & $\begin{array}{l}13.4 \mathrm{~g} \\
23 \mathrm{mM}\end{array}$ & $268 \mathrm{U}$ His-VAO CFE & 37 & 51 & 1.9 & & 93 & 9.2 & 1.1 \\
\hline $\mathrm{f}^{[\mathrm{a}]}$ & GC & $\begin{array}{l}10.0 \mathrm{~g} \\
23 \mathrm{mM}\end{array}$ & 202 U His-VAO CFE & 6.0 & 82 & 4.1 & & 90 & 6.5 & 1.0 \\
\hline & ${ }^{1} \mathrm{H}-\mathrm{NMR}$ & & & 6.3 & & & 89 & & 2.7 & 1.8 \\
\hline
\end{tabular}

\footnotetext{
${ }^{[a]}$ Reaction vessel was kept under pure $\mathrm{O}_{2}$ atmosphere for the first $9 \mathrm{~h}$.
} 
substrate with $0.02 \mathrm{U} \mathrm{VAO} / \mathrm{mg}$ substrate was chosen as the conditions for scale-up.

As the costs associated with protein purification could be a major hurdle for the use of enzymatic conversions in an industrial setting, we subsequently tested whether we could eliminate this step by performing the reaction using a cell-free extract of Escherichia coli expressing an N-terminally His-tagged variant of VAO. The plasmid encoding for this Histagged VAO, pJ404-His-VAO, contains a version of the gene encoding for VAO that is codon-optimised for expression in E. coli. This construct allows VAO to be expressed at higher levels than the previously used plasmid, pBC11, ${ }^{[35]}$ which contains the vao $A$ gene from $P$. simplicissimum. Using this cell-free extract, the conversion of $100 \mathrm{mg} \mathbf{1}$ gave a similar result to that using the purified enzyme (Table 2, reaction c). Apparently, the use of $E$. coli cell-free extract did not lead to any undesired side reactions taking place. Therefore, the cell-free extract was used for further scale-up reactions.

Having established the optimised reaction conditions for the conversion of $\mathbf{1}$ to $\mathbf{2}$, we next set out to scale up the reaction to a more synthetically relevant scale of $10 \mathrm{~g}$ of substrate. First, the reaction was scaled up to $1 \mathrm{~g}$ of substrate using the same reaction conditions as for $100 \mathrm{mg}$. This led to almost complete conversion (93\%) of $\mathbf{1}$ and to similar formation of $\mathbf{2}$ as was obtained at $100 \mathrm{mg}$ scale (Table 2 , reaction d). Analysis of the reaction products by ${ }^{1} \mathrm{H}-\mathrm{NMR}$ allowed quantification of the products without being hindered by the decomposition of 1-(4'-hydroxyphenyl)ethanol to 4 observed during GC analysis, revealing that the enzymatic reaction yields less than $3 \%$ of $\mathbf{4}$ as a sideproduct (Table 2 , reaction $\mathrm{d}$ ). To obtain pure $\mathbf{2}$, it was purified from the crude reaction mixture by recrystallisation, yielding $244.3 \mathrm{mg}$ (21\%) pure 2 at $99 \%$ ee (Figures S3+S4).

Subsequently, the reaction was scaled up to our final target scale of approximately $10 \mathrm{~g}$ of starting material. However, using the same reaction conditions with $13.4 \mathrm{~g} 1$ led to lower conversion of the substrate [63\% (Table 2, reaction e)]. TLC analysis revealed that the reaction was essentially complete after $9 \mathrm{~h}$, with no further product formation being observed after this time. Possibly, the reaction does not proceed further due to inactivation of the enzyme. As the large volume used for this reaction could lead to oxygen depletion becoming rate-limiting, we performed the reaction with $10 \mathrm{~g} \mathbf{1}$ under identical conditions, but with the reaction vessel under oxygen atmosphere for the first $9 \mathrm{~h}$ of the reaction to try and increase the conversion of the substrate. Under these conditions, the substrate was almost completely converted after $24 \mathrm{~h}$ [94\% (Table 2, reaction $\mathrm{f}$ )]. TLC analysis again revealed that the reaction was essentially complete after $9 \mathrm{~h}$ under oxygen atmosphere. Extraction of the reaction mixture with ethyl acetate yielded $6.51 \mathrm{~g}$ crude product. Based on the $82 \%$ formation of 2 observed in the GC experiments, a crude yield of $5.34 \mathrm{~g}(47 \%) 2$ can be estimated. After recrystallisation, pure 2 was obtained in $36 \%$ isolated yield and $97 \%$ ee (Figures S3+S4). The observation that maintaining sufficient oxygen levels is crucial to allow the reaction to proceed is in agreement with previous studies regarding biotransformations using monooxygenase-containing whole-cell biocatalysts, where oxygen depletion was found to be limiting for the reaction under certain conditions. ${ }^{[8,36,37]}$ Although we were able to maintain sufficient oxygen levels by performing the reaction under an oxygen atmosphere, this may not be suitable for an industrial-scale reaction as the use of pure oxygen poses an explosion hazard. Use of alternative systems to achieve sufficient oxygen levels, such as bubble aeration could provide a solution for industrial-scale transformations. ${ }^{[38]}$ One aspect of the process that can be improved upon is the fact that, despite observing $82 \%$ formation of $\mathbf{2}$ in the largestscale reaction, the isolated yield is relatively low at $36 \%$. This low yield is attributable to significant losses of material during both the extraction of the product from the reaction mixture $(6.51 \mathrm{~g}$ crude product obtained from $10 \mathrm{~g}$ starting material) and during recrystallisation. The loss of material during the extraction procedure may be attributable to the relatively high polarity of the product making its extraction into organic solvents inefficient. This may be solved in future by testing other solvents for extraction or by performing more rounds of extraction. From the GC data, it can be calculated that the crude compound obtained after extraction contains $5.34 \mathrm{~g} \mathrm{2}$, which corresponds to a crude yield of $47 \%$. This means that a further $23 \%$ of the product was lost during its purification by recrystallisation. Although this loss is significant, recrystallisation is likely the most efficient method to increase the ee of the product by removing the $(S)-1-\left(4^{\prime}\right.$-hydroxyphenyl)ethanol formed as a side-product.

1-(4'-Hydroxyphenyl)ethanol can also be biocatalytically synthesised by the hydration of 4-vinylphenol using phenolic acid decarboxylase (PAD). ${ }^{[20,22]}$ All tested PADs preferentially yielded the $(S)$-enantiomer of 1-(4'-hydroxyphenyl)ethanol, providing a potential route to the opposite enantiomer than that formed by VAO.

Here, we described the scale-up of the synthesis of (R)-1-(4'-hydroxyphenyl)ethanol by the enantioselective hydroxylation of 4-ethylphenol by VAO. Under optimised reaction conditions, 94\% conversion of $10 \mathrm{~g}$ 4-ethylphenol was obtained after $24 \mathrm{~h}$. Purification of the product yielded $(R)-1-(4$ '-hydroxyphenyl)ethanol in $36 \%$ isolated yield and $97 \%$ ee. These results highlight some of the issues that may be encountered during scale-up of an enzymatic hydroxylation reac- 
tion from analytical scale to a synthetically relevant scale and may be of use in facilitating such scale-up for the synthesis of chiral pharmaceutical intermediates in an industrial setting.

\section{Experimental Section}

\section{Materials}

4-Ethylphenol and 4-hydroxyacetophenone were from abcr (Karlsruhe, Germany). An analytical standard for 1-(4'hydroxyphenyl)ethanol was synthesised as a racemic mixture from 4-hydroxyacetophenone:

A solution of 4-hydroxyacetophenone $(3.4 \mathrm{~g}, 25 \mathrm{mmol})$ in $\mathrm{MeOH}(50 \mathrm{~mL})$ was stirred at $15-20^{\circ} \mathrm{C}$ and a solution of $\mathrm{NaBH}_{4}(0.57 \mathrm{~g}, 15 \mathrm{mmol})$ in $0.2 \mathrm{M}$ aqueous $\mathrm{NaOH}(10 \mathrm{~mL})$ was added. Subsequently, the reaction mixture was stirred at room temperature for $20 \mathrm{~h}$. After this, $\mathrm{MeOH}$ was removed by evaporation and water $(10 \mathrm{~mL})$ was added to the residue. The mixture was extracted with $\mathrm{CHCl}_{3}$ /isopropanol (3/1) and the organic layer was dried over $\mathrm{Na}_{2} \mathrm{SO}_{4}$ and the solvent was removed by evaporation. The residue $(2.2 \mathrm{~g}$, yellow solid) was chromatographed on silica gel with dichloromethane/ $\mathrm{MeOH}$ (50/1), yielding pure $(R, S)-1-\left(4^{\prime}\right.$-hydroxyphenyl $)$ ethanol $(1.45 \mathrm{~g}$, white solid, $42 \%)$. The elution times of the enantiomers upon gas chromatography analysis were assigned by comparison with 1-(4'-hydroxyphenyl)ethanol formed by conversion of $\mathbf{1}$ by VAO [primarily $(R)$-enantiomer].

${ }^{1} \mathrm{H}-\mathrm{NMR}\left(\mathrm{d}_{6}\right.$-DMSO, $\left.400 \mathrm{MHz}\right): \delta(\mathrm{ppm}): 9.10$ (s, 1H, Ar$\mathrm{OH}), 7.12(\mathrm{dt}, \mathrm{J}=8.02 \mathrm{~Hz}, 2 \mathrm{H}, \mathrm{Ar}-\mathrm{H}), 6.68(\mathrm{dt}, \mathrm{J}=8.69 \mathrm{~Hz}$, $2 \mathrm{H}, \mathrm{Ar}-\mathrm{H}), 4.85(\mathrm{~d}, \mathrm{~J}=4.29 \mathrm{~Hz}, 1 \mathrm{H}$, aliph.-OH), 4.63-4.57 $(\mathrm{m}, 1 \mathrm{H}, \mathrm{CH}), 1.27$ (d, J =6.44 Hz, 3H, CH3).

All other chemicals were from commercial sources and of the purest grade available.

\section{Expression and Purification of VAO}

For small-scale tests with purified enzyme, VAO was expressed and purified as described previously. ${ }^{[39]}$ For largerscale reactions using cell-free extracts, N-terminally Histagged VAO was expressed from the pJ404-His-VAO plasmid, which contains a version of the vaoA gene from $P$. simplicissimum that is codon-optimised for expression in $E$. coli behind an IPTG-inducible T5 promoter. BL21 E. coli cells containing this plasmid were grown at $37^{\circ} \mathrm{C}$ in $\mathrm{LB}$ medium containing $100 \mu \mathrm{g} / \mathrm{mL}$ ampicillin until the $\mathrm{OD}_{600}$ of the cultures was 0.6. Subsequently, IPTG was added to a concentration of $0.8 \mathrm{mM}$ and the cells were grown overnight at $25^{\circ} \mathrm{C}$. Following this, cells were harvested by centrifugation $\left(4,000 \mathrm{~g}, 10 \mathrm{~min}, 10^{\circ} \mathrm{C}\right)$, resuspended in $50 \mathrm{mM}$ potassium phosphate buffer, $\mathrm{pH} 7.0$, containing $0.5 \mathrm{mM}$ dithiothreitol, $0.5 \mathrm{mM} \mathrm{MgSO}_{4}$ and one cOmplete ${ }^{\mathrm{TM}}$ protease inhibitor pill (Roche, Basel, Switserland) and $1 \mathrm{mg}$ DnaseI (Roche) per $50 \mathrm{~mL}$, and lysed by passing them through a pre-cooled SLM Aminco French Pressure Cell three times. Subsequently, cell debris was removed by centrifugation $(39,000 \mathrm{~g}$, $45 \mathrm{~min}, 4^{\circ} \mathrm{C}$ ) and the obtained soluble fractions were used for the reactions.
VAO activity was determined by monitoring the conversion of vanillyl alcohol (4-hydroxy-3-methoxybenzyl alcohol) to vanillin (4-hydroxy-3-methoxybenzaldehyde) at $25^{\circ} \mathrm{C}$ in $50 \mathrm{mM}$ potassium phosphate buffer, $\mathrm{pH} 7.5$, by measuring the absorption of the product at $340 \mathrm{~nm} \quad(\varepsilon=$ $14,000 \mathrm{M}^{-1} \mathrm{~cm}^{-1[24]}$ ) using a Hewlett Packard 8453 diode array spectrophotometer (Agilent Technologies, Santa Clara, CA, USA).

\section{Gas Chromatography}

Gas chromatography experiments were performed on a GC2010 plus (Shimadzu, Kyoto, Japan) with an FID detector $\left(260^{\circ} \mathrm{C}\right)$ and a Hydrodex $\beta-6$ TBDM column $(25 \mathrm{~m} \times$ $2.45 \mathrm{~mm}$, Machery-Nagel, Düren, Germany). Hydrogen was used as a carrier gas at a flow rate of $1.5 \mathrm{~mL} / \mathrm{min}$ and the injector temperature was $80^{\circ} \mathrm{C}$. Runs were performed using a 20 min gradient from 80 to $220^{\circ} \mathrm{C}$ followed by $10 \mathrm{~min}$ at $220^{\circ} \mathrm{C}$.

\section{Analytical-Scale Conversions of 4-Ethylphenol}

$1(5 \mathrm{mg}, 41 \mu \mathrm{mol})$, VAO $(0.4 \mathrm{U}, 0.8 \mathrm{~mL}$ of a $0.5 \mathrm{U} / \mathrm{mL}$ solution in $50 \mathrm{mM}$ potassium phosphate buffer, $\mathrm{pH} 7.5$ ) the specified organic solvent $(1.4 \mathrm{~mL})$ and $100 \mathrm{mM}$ potassium phosphate buffer, $\mathrm{pH} 7.5$, (11.8 mL) were incubated at $30^{\circ} \mathrm{C}$. The reaction was performed in a $25 \mathrm{~mL}$ flask that was open to air and the reaction mixture was stirred using a magnetic stirrer. The stirrer speed was adjusted so as to form a whirlpool in the solution to achieve maximal aeration. After the reaction, the solution was concentrated under reduced pressure. The residue was extracted with EtOAc $(4 \times 5 \mathrm{~mL})$. The organic layer was dried over $\mathrm{Na}_{2} \mathrm{SO}_{4}$ and filtered, and the solvent was removed by evaporation. The residue was dissolved in $\mathrm{MeOH}(1 \mathrm{~mL})$ and analysed by GC.

Scale-up to the $100 \mathrm{mg}$ scale was performed using the same procedure, but with the volume of the reaction mixture adapted to achieve the desired substrate concentration and using 2 U VAO (or His-VAO cell-free extract). Reactions were performed in $100 \mathrm{~mL}$ flasks that were open to air.

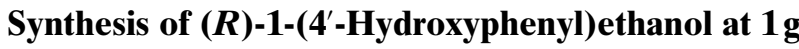 Scale}

1 ( $1 \mathrm{~g}, 8.2 \mathrm{mmol})$ was dissolved in acetone $(34.5 \mathrm{~mL})$. $100 \mathrm{mM}$ potassium phosphate buffer, $\mathrm{pH} 7.5,(296 \mathrm{~mL})$ and His-VAO cell-free extract $(20 \mathrm{U}, 14.3 \mathrm{~mL}$ of a $1.4 \mathrm{U} / \mathrm{mL}$ solution) were added to the solution. Reactions were performed in a $1 \mathrm{~L}$ flask that was open to air and the reaction mixture was stirred using a magnetic stirrer. The stirrer speed was adjusted so as to form a whirlpool in the solution to achieve maximal aeration. The reaction solution was stirred for $24 \mathrm{~h}$ at $30^{\circ} \mathrm{C}$ (water bath) under air atmosphere. After $24 \mathrm{~h}$, the solution was concentrated under reduced pressure at $50^{\circ} \mathrm{C}$ (water bath). During concentration, a slimy white solid was formed. The suspension was filtered and the aqueous phase was extracted with EtOAc. The organic phase was washed with brine, dried over $\mathrm{Na}_{2} \mathrm{SO}_{4}$ and concentrated under reduced pressure to give a crude compound (502 mg, green beige solid). This compound was analysed by GC and 
${ }^{1} \mathrm{H}-\mathrm{NMR}$ to evaluate the success of the conversion. Subsequently, the crude product was purified by recrystallisation. EtOAc $(3 \mathrm{~mL})$ was added to the crude product and the suspension was heated to $80^{\circ} \mathrm{C}$ (oil bath) until all solid was dissolved. Subsequently, the solution was cooled to room temperature, during which a solid crystallised. The solid was filtered and washed with a hexane/EtOAc mixture (1/1). The solid was dried under reduced pressure at $50{ }^{\circ} \mathrm{C}$ (water bath) to give the product ( $244.3 \mathrm{mg}$, white solid, $22 \%$ ).

\section{Synthesis of (R)-1-(4'-Hydroxyphenyl)ethanol at $10 \mathrm{~g}$ Scale}

$1(10 \mathrm{~g}, 82 \mathrm{mmol})$ was dissolved in acetone $(345 \mathrm{~mL})$. $100 \mathrm{mM}$ potassium phosphate buffer, $\mathrm{pH} 7.5,(3075 \mathrm{~mL})$ and His-VAO cell-free extract $(202 \mathrm{U}, 31 \mathrm{~mL}$ of a $6.5 \mathrm{U} / \mathrm{mL}$ solution) were added to the solution. The reaction was performed in a $4 \mathrm{~L}$ flask and the solution was stirred with an overhead stirrer $(230 \mathrm{rpm})$. The reaction vessel was evacuated and then brought under $\mathrm{O}_{2}$ atmosphere using a balloon filled with $\mathrm{O}_{2}$ gas. The solution was stirred for $9 \mathrm{~h}$ under $\mathrm{O}_{2}$ atmosphere and, subsequently, $15 \mathrm{~h}$ under air atmosphere at $30^{\circ} \mathrm{C}$ (water bath). After $24 \mathrm{~h}$, the solution was concentrated under reduced pressure at $50^{\circ} \mathrm{C}$ (water bath). During concentration, a slimy white solid was formed. The suspension was filtered and the aqueous phase $(\approx 1 \mathrm{~L})$ was extracted with EtOAc $(1 \times 1 \mathrm{~L}$, then $3 \times 500 \mathrm{~mL})$. The organic phase was washed with brine, dried over $\mathrm{Na}_{2} \mathrm{SO}_{4}$ and concentrated under reduced pressure to give a crude compound $(6.51 \mathrm{~g}$, green beige solid). This compound was analysed by $\mathrm{GC}$ and ${ }^{1} \mathrm{H}-\mathrm{NMR}$ to evaluate the success of the conversion. Subsequently, the crude product was purified by recrystallisation. EtOAc $(38 \mathrm{~mL})$ was added to the crude compound and the suspension was heated to $90^{\circ} \mathrm{C}$ (oil bath) until all solid was dissolved. Subsequently, the solution was cooled to room temperature, during which a solid crystallised. The solid was filtered and washed with a hexane/ EtOAc mixture (1/1). The solid was dried under reduced pressure at $50^{\circ} \mathrm{C}$ (water bath) to give the product $(4.10 \mathrm{~g}$, white solid, $36 \%$ )

\section{Acknowledgements}

We would like to thank Prof. Dr. Marco Fraaije (University of Groningen, The Netherlands) for supplying the pJ404-His$V A O$ plasmid and Dr. Caroline Paul (Wageningen University \& Research) for critically reading the manuscript. This work was funded by the European Union under the INDOX project (FP7-KBBE-2013-7-613549).

\section{References}

[1] S. Enthaler, A. Company, Chem. Soc. Rev. 2011, 40, $4912-4924$.

[2] A. C. Lindhorst, S. Haslinger, F. E. Kühn, Chem. Commun. 2015, 51, 17193-17212.

[3] E. G. Kovaleva, J. D. Lipscomb, Nat. Chem. Biol. 2008, $4,186-193$.
[4] H. Leisch, K. Morley, P. C. K. Lau, Chem. Rev. 2011, 111, 4165-4222.

[5] M. Hofrichter, R. Ullrich, Curr. Opin. Chem. Biol. 2014, 19, 116-125.

[6] H. M. Girvan, A. W. Munro, Curr. Opin. Chem. Biol. 2016, 31, 136-145.

[7] E. Romero, J. R. Gómez Castellanos, G. Gadda, M. W. Fraaije, A. Mattevi, Chem. Rev. 2018, 118, 1742-1769.

[8] B. Bühler, I. Bollhalder, B. Hauer, B. Witholt, A. Schmid, Biotechnol. Bioeng. 2003, 82, 833-842.

[9] C. V. F. Baldwin, R. Wohlgemuth, J. M. Woodley, Org. Process Res. Dev. 2008, 12, 660-665.

[10] R. Bernhardt, V. B. Urlacher, Appl. Microbiol. Biotechnol. 2014, 98, 6185-6203.

[11] D. Holtmann, M. W. Fraaije, I. W. C. E. Arends, D. J. Opperman, F. Hollmann, Chem. Commun. 2014, 50, 13180-13200.

[12] E. Fernández-Fueyo, Y. Ni, A. Gomez Baraibar, M. Alcalde, L. M. van Langen, F. Hollmann, J. Mol. Catal. B Enzym. 2016, 134, 347-352.

[13] A. T. Martínez, F. J. Ruiz-Dueñas, S. Camarero, A. Serrano, D. Linde, H. Lund, J. Vind, M. Tovborg, O. M. Herold-Majumdar, M. Hofrichter, et al., Biotechnol. $A d v$. 2017, 35, 815-831.

[14] G.-W. Zheng, J.-H. Xu, Curr. Opin. Biotechnol. 2011, 22, 784-792.

[15] U. Karl, A. Simon, Chim. Oggi 2009, 27, 66-69.

[16] R. N. Patel, Biomolecules 2013, 3, 741-777.

[17] W. Stampfer, B. Kosjek, K. Faber, W. Kroutil, J. Org. Chem. 2003, 68, 402-406.

[18] A. Neupert, T. Ress, J. Wittmann, W. Hummel, H. Gröger, Z. Naturforsch. B 2010, 65, 337-340.

[19] C. R. Silva, J. C. Souza, L. S. Araújo, E. Kagohara, T. P. Garcia, V. H. Pelizzari, L. H. Andrade, J. Mol. Catal. B Enzym. 2012, 83, 23-28.

[20] C. Wuensch, J. Gross, G. Steinkellner, K. Gruber, S. M. Glueck, K. Faber, Angew. Chem. Int. Ed. 2013, 52, 2293-2297.

[21] F. D. Nasário, T. Cazetta, P. J. S. Moran, J. A. R. Rodrigues, Tetrahedron: Asymmetry 2016, 27, 404-409.

[22] S. E. Payer, H. Pollak, S. M. Glueck, K. Faber, ACS Catal. 2018, 8, 2438-2442.

[23] Z.-S. Yang, J.-X. Wang, Y. Zhou, J.-P. Zuo, Y. Li, Bioorg. Med. Chem. 2006, 14, 8043-8049.

[24] E. de Jong, W. J. H. van Berkel, R. P. van der Zwan, J. A. M. de Bont, Eur. J. Biochem. 1992, 208, 651-657.

[25] M. W. Fraaije, C. Veeger, W. J. H. van Berkel, Eur. J. Biochem. 1995, 234, 271-277.

[26] R. H. H. van den Heuvel, M. W. Fraaije, C. Laane, W. J. H. van Berkel, J. Bacteriol. 1998, 180, 5646-5651.

[27] T. A. Ewing, A. van Noord, C. E. Paul, W. J. H. van Berkel, Molecules 2018, 23, 164.

[28] R. H. H. van den Heuvel, J. Partridge, C. Laane, P. J. Halling, W. J. H. van Berkel, FEBS Lett. 2001, 503, 213216.

[29] F. P. Drijfhout, M. W. Fraaije, H. Jongejan, W. J. H. van Berkel, M. C. R. Franssen, Biotechnol. Bioeng. 1998, 59, 171-177.

[30] M. W. Fraaije, W. J. H. van Berkel, J. Biol. Chem. 1997, 272, 18111-18116. 
[31] M. W. Fraaije, R. H. H. van den Heuvel, J. C. A. A. Roelofs, W. J. H. van Berkel, Eur. J. Biochem. 1998, 253, 712-719.

[32] T. A. Ewing, Q.-T. Nguyen, R. C. Allan, G. Gygli, E. Romero, C. Binda, M. W. Fraaije, A. Mattevi, W. J. H. van Berkel, J. Biol. Chem. 2017, 292, 14668-14679.

[33] R. H. H. van den Heuvel, M. W. Fraaije, M. Ferrer, A. Mattevi, W. J. H. van Berkel, Proc. Natl. Acad. Sci. USA 2000, 97, 9455-9460.

[34] R. K. Kaltofen, Tabellenbuch Chemie, Verlag Harri Deutsch, 1998.
[35] R. H. H. van den Heuvel, M. W. Fraaije, A. Mattevi, W. J. H. van Berkel, J. Biol. Chem. 2000, 275, 1479914808.

[36] C. V. F. Baldwin, J. M. Woodley, Biotechnol. Bioeng. 2006, 95, 362-369.

[37] I. Hilker, C. Baldwin, V. Alphand, R. Furstoss, J. Woodley, R. Wohlgemuth, Biotechnol. Bioeng. 2006, 93, 1138-1144.

[38] F. Garcia-Ochoa, E. Gomez, Biotechnol. Adv. 2009, 27, 153-176.

[39] T. A. Ewing, G. Gygli, W. J. H. van Berkel, FEBS J. 2016, 283, 2546-2559. 